\section{The morphological study and gene expression analysis in citrus hybrid with a short juvenile period}

\author{
Luciana Silva Almeida ${ }^{1}$, Eliana Maria Rocha Sousa ${ }^{1}$, Paulo \\ Henrique da Silva ${ }^{2}$, Tahise Magalhães Oliveira ${ }^{1}$, Alex-Alan \\ Furtado de Almeida ${ }^{1}$, Mauricio Antônio Coelho Filho ${ }^{3}$, Walter \\ dos Santos Soares Filho ${ }^{3}$ and Abelmon da Silva Gesteira ${ }^{1,3^{*}}$
}

\begin{abstract}
Citrus plants have a long juvenile period, which has hampered the breeding progress of these species. In this sense, research focused on reducing the juvenile phase is needed to accelerate the breeding process. In this study, the morphology of the hybrid \{[('Rangpur' lime) x YMCT ('Yuma' citrange) - 005] $x$ (Microcitrus papuana) - 001\} (H011), which has a short juvenile period, and the gene expression levels of the FLOWERING LOCUS T (FT) were evaluated. Morphological studies indicated early flowering and fruiting of the hybrid, characteristics that make it a promising candidate for citrus breeding. In addition, winter temperatures influenced the expression of the FT gene in stems and leaves.
\end{abstract}

Keywords: Flower, Citrus spp, floral induction, FT gene.

\section{INTRODUCTION}

The life cycle of higher plants is characterized by two development stages, the vegetative and the reproductive. The former consists of the juvenile and adult vegetative stages. During the juvenile vegetative phase, the plants are unable to flower, even under inductive conditions. In certain perennial plants, this period can persist for several decades (Amasino 2010, Yamagishi et al. 2014). Many Citrus species with an extensive juvenile period will produce neither flowers nor fruits for many years, decades or even longer (Davies and Jackson 2009, Pajon et al. 2017). This long juvenile phase bars the use of genetic strategies to improve responses to environmental stress, fruit quality and disease resistance (Krajewski and Rabe 1995, Velázquez et al. 2016, Pajon et al. 2017).

The transition from the juvenile to the adult stage involves exogenous and endogenous factors, controlled by a pool of complex genes, and depends on the duration of the juvenile stage (Dornellas et al. 2007, Song et al. 2013, Ha 2014). Molecular studies suggested that the FLOWERING LOCUS T (FT) is an important part of the flowering hormone and the primary component of the flowering signal cascade (Lemmetyinen et al. 2004, Corbesier et al. 2007, Kong et al. 2010, Imamura et al. 2011, Velázquez et al. 2016). The FT gene and homologous genes, reported in a wide variety of plants, play similar and important roles. Many studies have shown that an $F T$ overexpression can promote early flowering
Crop Breeding and Applied Biotechnology 19(3), 262-268, 2019 Brazilian Society of Plant Breeding. Printed in Brazil http://dx.doi.org/10.1590/198470332019v19n3a37

\section{*Corresponding author: E-mail: abelmon.gesteira@embrapa.br (i) ORCID: 0000-0002-7590-0455}

Received: 05 February 2018 Accepted: 11 February 2019

${ }^{1}$ Universidade Estadual de Santa Cruz, Departamento de Ciências Biológicas, 45.662-900, Ilhéus, Bahia, Brazil

${ }^{2}$ Universidade Federal do Recôncavo da Bahia, Departamento de Ciências Biológicas, 44.380-000, Cruz das Almas. Bahia, Brazil ${ }^{3}$ Embrapa Mandioca e Fruticultura, Cruz das Almas, 44.380-000, Bahia, Brazil 
in transgenic plants (Kojima et al. 2002, Endo et al. 2005, Bohleninus et al. 2006, Hsu et al. 2006, Lifschitz et al. 2006, Nakatsuka et al. 2009, Xu et al. 2012). Moreover, FT expression facilitates vernalization and flowering pathways and can induce flowering. (Huang et al. 2005, Corbesier et al. 2007, Xu et al. 2012).

Several studies have been performed to elucidate the molecular mechanisms involved in flower formation and differentiation in citrus. In transgenic plants of the trifoliate orange (Poncirus trifoliata L. Raf.), the constitutive expression of the citrus FT gene (CiFT) induced flowering after 12 weeks, unlike the generally several-year-long juvenile phase in wild-type plants (Endo et al. 2005). The expression of flowering-related genes and the function of low temperatures for floral induction were studied in Satsuma mandarin (Citrus unshiu Marc.). Only in adult Satsuma mandarin trees, flowering is triggered by low temperatures, by activation of CiFT transcription, while in the juvenile plant, CiFT transcription is irresponsive to cold (Nishikawa et al. 2007, Nishikawa et al. 2009). The constitutive expression of the FT gene of Arabidopsis thaliana and $C$. sinensis, by means of a virus vector based on citrus leaf spot virus, was able to induce flowering in juvenile plants of a variety of citrus types (Velázquez et al. 2016). In a mature tree of pummelo (C. grandis Osbeck) and 'Pineapple' sweet orange (C.sinensis (L.) Osbeck), it was observed that the CiFT gene is probably involved with shoot apex differentiation and flower bud determination, but not associated with dormancy interruption and further flower bud development (Pajon et al. 2017).

Exploiting the wide genetic variability contained in the Active Germplasm Bank (BAG), the Citrus Breeding Program of Embrapa Cassava and Fruits (Cruz das Almas, Bahia, Brazil) selected hybrids with a short juvenile period. Among these citrus hybrids, \{[('Rangpur' lime) x YMCT ('Yuma' citrange) - 005] x (Microcitrus papuana) - 001\} (H011) is particularly outstanding, with a juvenile period of one year. Thus, this study addressed the morphological characterization of this hybrid [(LCR x CTYM - 005) x MCP - 011], named Microcitrangemonia 11, and investigated the effect of differentiated FT expression levels on the reduction of its juvenile phase.

\section{MATERIAL AND METHODS}

\section{Plant material and morphological characterization}

The experiment was carried out on an experimental field of Embrapa Cassava and Fruits (lat 12 40'19" S, long 390 06' 22" W, and alt $220 \mathrm{~m}$ asl), in Cruz das Almas, Bahia, Brazil. Three approximately 4-year-old plants of the hybrid \{[('Rangpur' lime) x YMCT ('Yuma' citrange) - 005] x (Microcitrus papuana) - 001\} (H011), grafted onto (Citrus sunki x Poncirus trifoliata), were evaluated. In addition, the female parent $\{$ [('Rangpur' lime) x YMCT ('Yuma' citrange) - 005] and male parent (Microcitrus papuana) - 001 were grafted on the same rootstock as the hybrid.

Thirty matures leaves of each plant were collected and analyzed. Ten fruits and 10 flowers were also evaluated. Morphologic traits were chosen from among the Descriptors for Citrus of the International Board for Plant Genetic Resources (IBPGR 1999). Among the 28 selected descriptors, 17 were qualitative and 11 quantitative. Of the qualitative descriptors, seven were related to fruit appearance [fruit shape, fruit apex shape, pulp texture, seed shape, seed surface, and seed and pulp color], five to leaf aspects [leaf shape, leaf blade margin, petiole type, intensity of green color of the leaf blade] and five to flower traits [flower type, flower arrangement, flower, anther color, color of open flower]. In turn, of the quantitative descriptors, three were related to fruit traits [fruit diameter, number of seeds per fruit, fruit weight], five to flower traits [number of petals per flower, petal width, calyx diameter, pedicel length, anther length relative to stigma] and three leaf traits [ leaf length, leaf width, leaf thickness].

\section{Confirmation of the nucellar clones}

To confirm the nucellar origin, genomic DNA was extracted from the leaves of Microcitrangemonia 11, as proposed by Murray and Thompson (1980). Microsatellite markers were amplified from the following pairs of primers: miCrCIR01E02, IC06A05b, CMS14, OT4S, CMS26 [Supplementary Table 1] (Yong et al. 2006, Froelicher et al. 2008, Cristofani-Yaly et al.

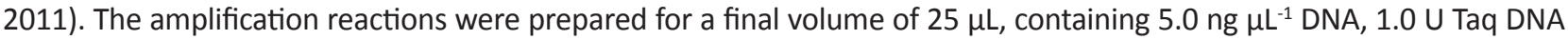
polymerase, $10 \mathrm{X}$ buffer ( $500 \mathrm{mM} \mathrm{KCl}, 100 \mathrm{mM}$ Tris- $\mathrm{HCl}, \mathrm{pH} 8$ Invitrogen), $1.0 \mathrm{mM} \mathrm{MgCl}$, dNTP $(0.2 \mathrm{mM})$, and $0.2 \mu \mathrm{M}$ of each primer. The PCR protocol consisted of: after initial denaturation, 35 cycles of $30 \mathrm{~s}$ at $94 \stackrel{\circ}{\circ}, 30 \mathrm{~s}$ at 52 으 and a final elongation step of $45 \mathrm{~s}$ at $72{ }^{\circ} \mathrm{C}$. The annealing temperature was $65^{\circ} \mathrm{C}$, decreasing $0.3^{\circ} \mathrm{C}$ per cycle, followed by three annealing cycles at $56^{\circ} \mathrm{C}$. The PCR products were visualized on $3 \%$ agarose gel stained with ethidium bromide $\left(0.5 \mathrm{ng} \mathrm{mL}^{-1}\right)$. 


\section{RNA extraction and cDNA synthesis}

After confirming the nucellar clones, they were divided into two groups: i) plants with early flowering; ii) plants without flowering. The samples were collected in two different seasons: winter (August/2015) and summer (February/2016). Total RNA was isolated with the kit RNAqueous ${ }^{\circledR}$ (Applied Biosystems, Ambion), according to the manufacturer's recommendations. Three independent biological replicates with 10 samples of leaves, buds and stems were collected, frozen in liquid nitrogen and stored at $-80 \stackrel{\circ}{\circ}$.

The RNA samples were treated with TURBO DNA-free (Applied Biosystems, Ambion) prior to reverse transcription.

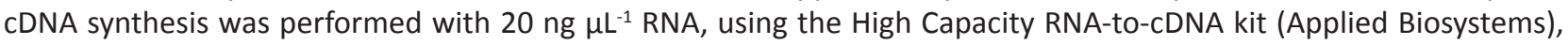
according to the manufacturer's instructions.

\section{Gene expression analysis}

Gene expression levels were measured with reverse - transcription quantitative real-time PCR (RT-PCR), using ABI 7500 FAST Real-Time PCR System (Applied Biosystems, Foster City, CA, USA). Real-time PCR was performed in triplicate, in $20 \mu \mathrm{L}$ reaction volumes; each reaction contained $100 \mathrm{ng}$ CDNA, $0.6 \mu \mathrm{L}$ of each primer $(10 \mu \mathrm{M}), 6.0 \mu \mathrm{L}$ of the Power $\mathrm{SYBR}^{\circledR}$ Green Master Mix (Thermo Fisher Scientific) and $0.8 \mu \mathrm{L}$ sterile Milli-Q water. The reaction parameters were set as follows: 1) activation of Taq DNA Polymerase at 95 으 for $2 \mathrm{~min} ; 2$ ) denaturation at 94 으 for $45 \mathrm{~s} ; 3$ ) annealing at 60 oC for 45s; and 4) extension at 72 으 for 1 min. Steps 3-4 were repeated for 40 cycles.

The comparative $\mathrm{Ct}(\triangle \Delta \mathrm{CT})$ method was used to quantify the gene expression, and the data were derived from three biological replicates. The Dissociation Curve software 1.0 (Applied Biosystems, EUA) detected that only one PCR product was generated by amplification (Additional file: 2). The glyceraldehyde-3-phosphate dehydrogenase C2 (GAPC2) [Supplementary Table 2] (Mafra et al. 2012) was used as endogenous. The FLOWERING LOCUS T (FT) primer [Supplementary Table 2] was designed based on the analysis of the sequences of Citrus sinensis (gi|568875304|ref| XM_006490681.1 | and orange1.1g037140m) and Citrus clementina (Ciclev10009697m) available at the National Center for Biotechnology Information (NCBI) and Phytozome v.9.1. Samples of early flowering plants of this study were used in further studies of gene expression.

The statistical analysis of gene expression in the different seasons was based on mean comparison by the Tukey test at $p<0.05$ in all cases.

\section{RESULTS AND DISCUSSION}

\section{Morphological characterization}

The hybrid Microcitrangemonia 11 is a medium-sized plant $(250 \mathrm{~cm}, 4$ years old), with a tree trunk diameter of approximately $200 \mathrm{~cm}$ (Figure 1A). The female parent (LCR X CTYM- 005) reaches a mean height of $280 \mathrm{~cm}$, while the male parent M. papuana is short, approximately $140 \mathrm{~cm}$ (Santos et al. 2015). The tree canopy is very dense and has an ellipsoid shape, with the presence of thorns on the branches, similar to the male parent.

The leaves are dark green, with simple division and sessile leaf attachment (Figure 1B). the leaf shape was classified as lanceolate, with dentate leaf margin and acute leaf apex. Moreover, the leaves have a single and continuous blade, similar to the male parent. The mean leaf length, width and thickness are listed in Table 1.

The juvenile phase of hybrid Microcitrangemonia 11 is short (approximately 1 year) and flowering is possible as of the second month of growth. Moreover, adult plants produce flowers several times in the same year, independently of environmental stimuli, and can even bear flowers and fruits all year long. These characteristics were not observed in the parents (Santos et al. 2015) and are not common in other citrus genotypes. In a sweet orange spontaneous earlyflowering mutant, named ' $x 11$ ', flowering occurs repeatedly in all seasons, without requiring environmental stimuli, except for pruning (Pinheiro et al. 2014). The flowers of Microcitrangemonia 11 are hermaphrodite, have a superior ovary and on average five petals per flower (Figure 1C). The anthers are yellow and relatively short in relation to the stigma. The quantitative characteristics such as calyx diameter, pedicel length and petal width and length are shown in Table 1.

The mean fruit weight of the hybrid Microcitrangemonia 11 was $15.39 \mathrm{~g}$. The fruit (Figure 1D) shape is spheroid, 


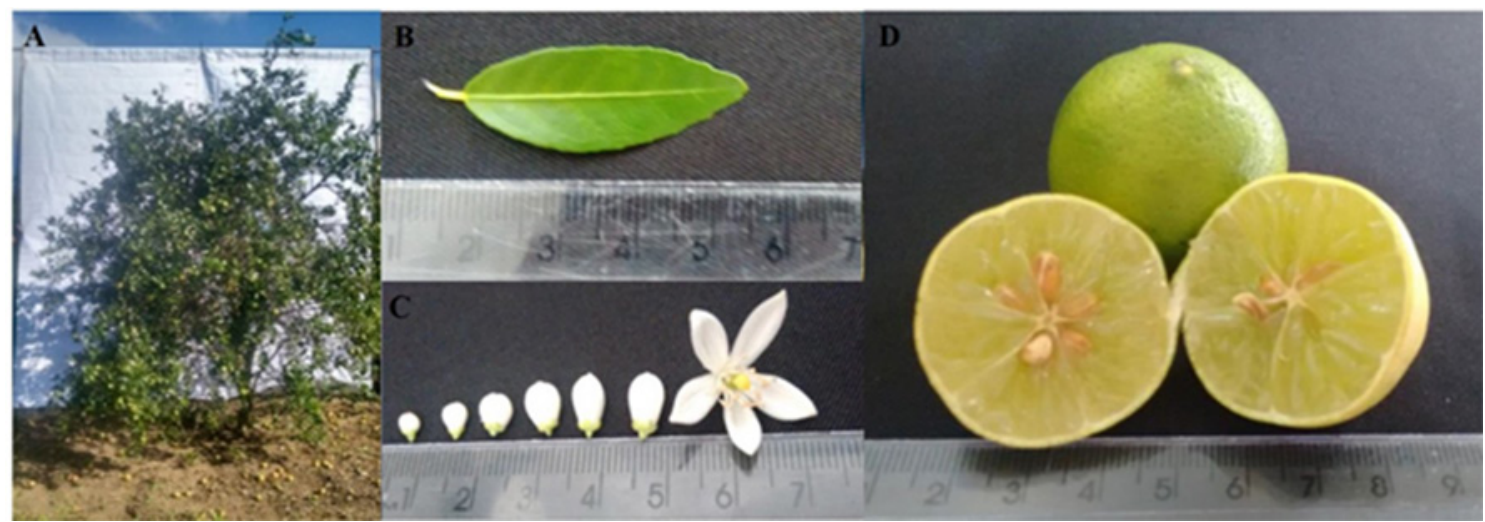

Figure 1. Hybrid \{[('Rangpur' lime) x YMCT ('Yuma' citrange) - 005] x (Microcitrus papuana) - 001\} (H011) of the Citrus Germplasm Collection of Embrapa Cassava and Fruits in Cruz das Almas, BA. Plant with aproximately four years old (A), fruits (B), flower buds and flower (C) and leaf blade (D).

the fruit base convex and the apex shape truncate, similar to that of the female parent. In contrast, the male parent had small elongated fruits and a crispy pulp texture (Santos et al. 2015). The mean fruit diameter and length of the studied hybrid and its parents are shown in Table 2. The mature fruit is yellowish green and has a smooth surface texture; fruits are produced in large amounts and have a strong fragrance and this trait makes them more attractive. These characteristics may be useful for the production of essential oils and with regard to the ornamental potential. The fruit pulp is light green and soft. In relation to seed, the hybrid produced an average of 10 viable seeds per fruit, with a medium size of $6.74 \mathrm{~mm}$ and spheroid shape. The seeds produced between one and five embryos and $50 \%$ polyembryony. Molecular analysis by microsatellite markers (SSRs) of 300 plants grown in a greenhouse showed that 132 plants were nucellar and 168 zygotic (data not shown).

\section{Gene expression of the FT gene}

Gene expression analysis demonstrated a major influence of low temperatures on FT expression in leaves and stems of hybrid Microcitrangemonia 11 (Figure 2). In the leaves, $F T$ gene expression was upregulated in the winter, while in the stem down-regulation was observed. The opposite was observed in the summer period, when there was a low regulation of the FT gene in leaves and increased expression in the stem. Among the environmental factors, the most important is temperature, followed by photoperiod and exposure to prolonged cold periods that induce vernalization (Amasino 2010, Srikanth and Schmid 2011, Huijer and Schmid 2011). Low temperatures induce FT gene expression, promoting floral induction in adult citrus trees (Valiente and Albrigo 2004, Nishikawa et al. 2007, Pajon et al. 2017). According to Nishikawa et al. (2007), a temperature of 15 ㄷ C is effective for floral induction in Satsuma mandarin, by means of an increase in the FT expression. In Poncirus trifoliata, floral development was observed in the winter when FT gene expression increased (Nishikawa et al. 2009).

Some studies indicate that in citrus, temperatures below $20^{\circ} \mathrm{C}$ can induce flowering (Valiente and Albrigo 2004, Nishikawa et al. 2007, Nishikawa et al. 2009). Our study showed that the mean winter temperature influenced the

Table 1. Morphological leaf and flower traits of hybrid $\{[($ 'Rangpur' lime) x YMCT ('Yuma' citrange) - 005] x (Microcitrus papuana) 001\} (H011)

\begin{tabular}{lc}
\hline Morphological traits & Mean $(\mathrm{mm})^{*}$ \\
\hline Leaf & \\
Length & $31.5 \pm 2.63$ \\
Width & $12.7 \pm 1.70$ \\
Thickness & $0.31 \pm 0.02$ \\
\hline Flower & \\
\hline Petal length & $11.0 \pm 0.73$ \\
Petal width & $4.4 \pm 0.49$ \\
Calyx diameter & $5.0 \pm 0.33$ \\
Pedicel length & $1.3 \pm 0.41$ \\
\hline
\end{tabular}

Table 2. Morphological fruit traits (in $\mathrm{mm}$ ) of the hybrid \{[('Rangpur' lime) x YMCT ('Yuma' citrange) - 005] x (Microcitrus papuana) - 001\} (H011) and its parents

\begin{tabular}{lccc}
\hline & \multicolumn{3}{c}{ Mean $(\mathrm{mm})^{*}$} \\
\cline { 2 - 4 } Trait & Hybrid & Female parent & Male parent \\
\hline Fruit diameter & $28.9 \pm 2.71$ & $38 \pm 0.10$ & $19 \pm 0.08$ \\
Fruit length & $32 \pm 3.62$ & $41 \pm 0.25$ & $54.5 \pm 0.38$ \\
\hline
\end{tabular}

* Mean value \pm Standard Error.

* Mean values \pm Standard Error. 


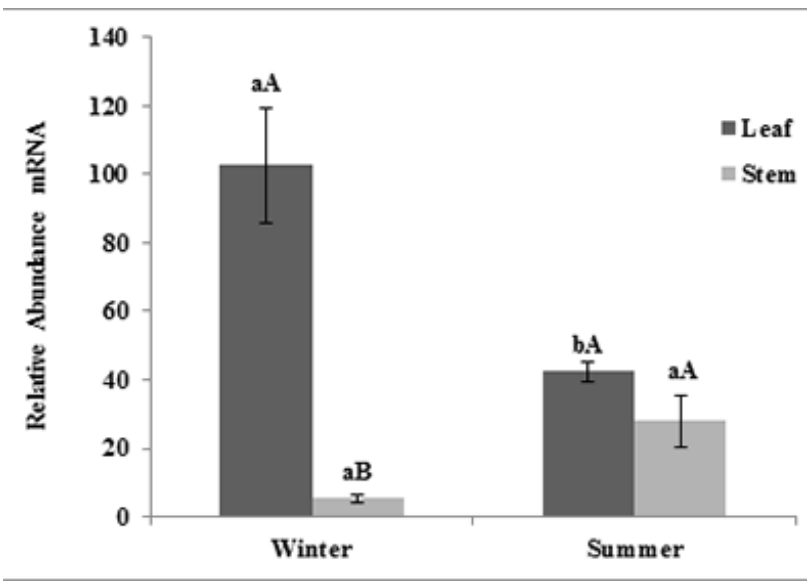

Figure 2. Expression of the FT gene in leaves and stem of hybrid Microcitrangemonia 11 in winter and summer. Vertical bars indicate the mean $\pm S E(n=3)$. Lowercase letters show differences between plant tissues in winter and summer; uppercase letters show differences between winter and summer $(P<0.05)$.

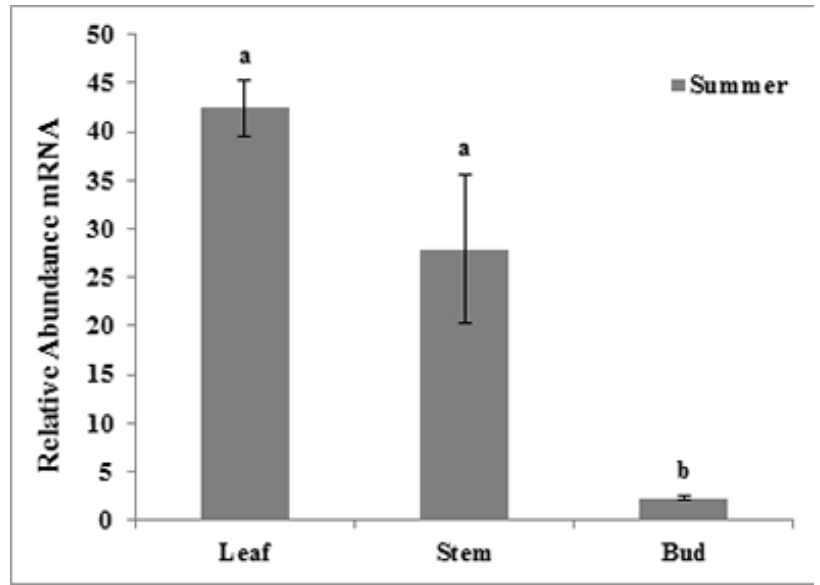

Figure 3. Expression of FT gene in leaves, stem and bud of hybrid Microcitrangemonia 11 in the summer. Vertical bars indicate the mean $\pm S E(n=3)$. Lowercase letters show differences between plant tissues in the summer.

FT expression, whereas the temperature pattern depends on the climatic conditions of the cultivation region (Davies and Albrigo 1994) and that this pattern varies according to the species (Ha and Johnston 2013). The stimulating effect of low temperatures on flowering is observed in both leaves and stem (Hall et al. 1977), however the upregulation in FT expression in citrus in winter can be explained by the capacity of the leaves to respond primarily to environmental stimuli such as temperature.

In the summer period, FT expression in the buds was also evaluated (Figure 3). The $F T$ levels were significant but down-regulated, compared to leaves and stem. In transgenic citrus (Kobayashi 1999) and apple plants (Kotoda et al. 2010), FT expression in buds was confirmed, although higher $F T$ levels were observed in leaves and stems, corroborating the results found in this study.

The flowering period of hybrid Microcitrangemonia 11 occurs a few months after the summer. The results found here suggest that the juvenile period was shortened and that the FT gene induced flowering in the studied plants. This confirms the findings of Endo et al. (2005), that the constitutive FT expression in P. trifoliata was able to significantly reduce the time of flowering induction in transgenic plants, highlighting the role of the FT gene as an important regulator of floral induction in citrus.

In grafting experiments with Arabidopsis thaliana mutants without the FT gene, the FT protein was transported from the rootstock to the scion where it promoted flowering (Xu et al. 2012). Moreover, the FT protein is transported from the leaves to the apical meristem, where floral differentiation occurs (Corbesier et al. 2007). In this sense, Nocker and Gardiner (2014) suggested that a stable transgenic line with constitutive FT expression could be used as rootstock to drive flowering of a transplanted graft. However, in the case of hybrid Microcitrangemonia 11, this is a natural characteristic, which is much more interesting for citrus breeding.

\section{CONCLUSION}

The evaluation of the morphological data indicated differences, mainly related to flowering, among different Microcitrangemonia 11 plants. Some seedlings produced flowers as of the second month of cultivation, and on adult trees, flowers and fruits were observed simultaneously throughout the year.

The levels of FT expression found in the different tissues of genotype Microcitrangemonia 11 confirmed an early juvenile period. It was also observed that the $F T$ gene induced flowering in these plants and that low temperatures influenced the $F T$ expression levels. 
The morphological study and gene expression analysis in citrus hybrid with a short juvenile period

This study provides insights into the effects of $F T$ expression and low temperatures on hybrid Microcitrangemonia 11. This genotype is a promising candidate for citrus breeding, although further analyses are needed to elucidate the molecular basis of its short juvenile period.

\section{ACKNOWLEDGMENTS}

The authors are indebted to the National Council for Scientific and Technological Development - CNPq (grant: 301356/2012-2 and 472733/2013-3). The Scholarship for Luciana Silva Almeida was financed by CAPES.

\section{REFERENCES}

Amasino R (2010) Seasonal and developmental timing of flowering. The Plant Journal 61: 1001-1013.

Bohleninus $\mathrm{H}$, Huang T, Charbonnel-Campaa L, Brunner AM, Jansson S, Strauss SH and Nilsson O (2006) CO/FT regulatory module controls timing of flowering and seasonal growth cessation in trees. Science 312: 1040-1043.

Corbesier L, Vincent C, Jang S, Fornara F, Fan Q, Searle I, Giakountis A, Farrona S, Gissot L, Turnbull C and Coupland G (2007) FT protein movement contributes to long-distance signaling in floral induction of Arabidopsis. Science 316: 1030-1033.

Cristofani-Yaly M, Novelli VM, Bastianel M and Machado MA (2011) Transferability and level of heterozygosity of microsatellite markers in Citrus species. Plant Molecular Biology Reporter 2: 418-423.

Davies FS and Albrigo LG (1994) Crop production science in horticulture: Citrus 2. CAB International, Wallingford, 254p.

Davies FS and Jackson LK (2009) Floridiana collection: citrus growing in Florida. University Press of Florida, Gainesville, 352p.

Dornellas MC, Boscariol Camargo, RL, Figueiredo LHM and Takita MA (2007) A genetic framework for flowering-time pathways in Citrus spp. Genetics and Molecular Biology 30: 769-779.

Endo T, Shimada T, Fujii H, Kobayashi Y, Araki T and Omura M (2005) Ectopic expression of an $F T$ homolog from citrus confers an early flowering phenotype on trifoliate orange (Poncirus trifoliata L. Raf.). Transgenic Research 14: 703-712.

Froelicher Y, Dambier D, Bassene JB, Costantino G, Lofty S, Didout C, Beaumont V, Brottier P, Risterucci AM, Luro F and Ollitraut P (2008) Characterization of microsatellite markers in mandarin orange (Citrus reticulate Blanco). Molecular Ecology Resources 8: 19-22.

Ha TM (2014) A review of plants' flowering physiology: the control of floral induction by juvenility, temperature and photoperiod in annual and ornamental crops. Asian Journal of Agriculture and Food Science 02: 186-195.

Ha TM and Johnston ME (2013) The effect of low temperature on flowering of Rhodanthe Floribunda. Asian Journal of Agriculture and Food Sciences 01: 205-209.

Hall AE, Khairi MMA and Asbell CW (1977) Air and soil temperature effects on flowering of citrus. Journal of the American Society for Horticultural Science 102: 261-263.
Hsu C-Y, Liu Y, Luthe DS and Yuceer C (2006) Poplar FT2 shortens the juvenile phase and promotes seasonal flowering. Plant Cell 18: 1846-1861.

Huang T, Böhlenius H, Eriksson S Parcy F and Nilsson O (2005) The mRNA of the Arabidopsis gene Ft moves from leaf to shoot apex and induces flowering. Science 9: 1694-1696.

Huijser P and Schmid M (2011) The control of developmental phase transition in plants. Development 138: 4117-4129.

IBPGR - International Board for Plant Genetic Resources Institute (1999) Descriptors for citrus. IBPGR, Rome, 66p.

Imamura T, Natatsuka T, Higuchi A, Nishihara M and Takahashi H (2011) The gentian orthologs of the FT/TFL1 gene family control floral initiation in Gentiana. Plant Cell Physiology 52: 1031-1041.

Kobayashi Y (1999) A pair of related genes with antagonistic roles in mediating flowering signals. Science 15: 1960-1962.

Kojima S, Kobayashi Y, Monna L, Sasaki T, Araki T and Yano M (2002) Hd3a, a rice ortholog of the Arabidopsis FT gene, promotes transition to flowering downstream of $\mathrm{Hd} 1$ under short-day conditions. Plant Cell Physiology 43: 1096-1105.

Kong F, Liu B, Xia Z, Sato S, Kim B, Watanabe S, Yamada T, Tabata S, Kanazawa A, Harada K and Abe J (2010) Two coordinately regulated homologs of FLOWERING LOCUS T are involved in the control of photoperiodic flowering in soybean. Plant Physiology 154: 12201231.

Kotoda N, Hayashi H, Suzuki M, Igarashi M, Hatsuyama Y, Kidou S, Igasaki T, Nishiquchi M, Yano K, Shimizu T, Takahashi S, Iwanami H, Moriya S and Abe K (2010) Molecular characterization of FLOWERING LOCUS $T$-like genes of apple ( Malus $\times$ domestica Borkh.). Plant \& Cell Physiology 51: 561-575.

Krajewski AJ and Rabe E (1995) Citrus flowering: a critical evaluation. Journal of Horticultural Science 70: 357-374.

Lemmetyinen J, Hassinen and Mand Elo A (2004) Functional characterization of SEPALLATA3 and AGAMOUS orthologues in silver birch. Physiology Plantarum 121: 149-162

Lifschitz E, Eviatar T, Rozman A, Shalit A, Goldshmidt A, Amsellem Z, Alvarez JP and Eshed $Y$ (2006) The tomato FT ortholog triggers systemic signals that regulate growth and flowering and substitute for diverse environmental stimuli. Proceedings National Academy of Sciences 103: 6398-6403. 


\section{LS Almeida et al.}

Mafra V, Kubo KS, Alves-Ferreira M, Ribeiro-Alves M, Stuart RM, Boava LP, Rodrigues CM and Machado MA (2012) Reference Genes for accurate transcript normalization in Citrus genotypes under different experimental conditions. PLoS ONE 7: e31263.

Murray MG and Thompson WF (1980) Rapid isolation of high molecular weight plant DNA. Nucleic Acids Research 8: 4321-4325.

Nakatsuka T, Abe Y, Kakizaki Y, Kubota A, Shimada N and Nishihara M (2009) Over-expression of Arabidopsis FT gene reduces juvenile phase and induces early flowering in ornamental gentian plants. Euphytica 168: 113-119.

Nishikawa F, Endo T, Shimada T, Fujii H, Shimizu T and Omura M (2009) Differences in seasonal expression of flowering genes between deciduous trifoliate orange and evergreen Satsuma mandarin. Tree Physiology 29: 921-926.

Nishikawa F, Endo T, Shimada T, Fujii H, Shimizu T, Omura M and Ikoma $Y$ (2007) Increased CiFT abundance in the stem correlates with floral induction by low temperature in Satsuma mandarin (Citrus unshiu Marc.). Journal of Experimental Botany 58: 3915-3927.

Nocker SV and Gardiner SE (2014) Breeding better cultivars, faster: applications of new technologies for the rapid deployment of superior horticultural tree crops. Horticulture Research 1: 1-8.

Pajon M, Febres VJ and Moore GA (2017) Expression patterns of flowering genes in leaves of 'Pineapple' sweet orange [Citrus sinensis (L.) Osbeck] and pummelo (Citrus grandis Osbeck). BMC Plant Biology 17: 146 .

Pinheiro TT, Figueira A and Latado RR (2014) Early-flowering sweet orange mutant ' $x 11$ ' as a model for functional genomic studies of Citrus. BMC Research Notes 7: 511.
Santos ARA, Souza EH, Souza FVD, Fadini M, Girardi EA and Soares Filho WS (2015) Genetic variation of Citrus and related genera with ornamental potential. Euphytica 205: 503-520.

Song YH, Ito S and Imaizumi T (2013) Flowering time regulation: photoperiod- and temperature-sensing in leaves. Trends in Plant Science 18: 575-583.

Srikanth A and Schmid M (2011) Regulation of flowering time: all roads lead to Rome. Cellular Molecular Life Science 68: 2013-2037.

Valiente JI and Albrigo LG (2004) Flower bud induction of sweet orange trees [Citrus sinensis (L.) Osbeck]: effect of low temperatures, crop load, and bud age. Journal of the American Society for Horticultural Science 129: 158-164.

Velázquez K, Agüero J, Vives MC, Aleza A, Pina JA, Moreno P and Navarro $L$ (2016) Precocious flowering of juvenile citrus induced by a viral vector based on Citrus leaf blotch virus: new tool for genetics and breeding. Plant Biotechnology Journal 14: 1976-1985.

Xu F, Rong X, Huang X and Cheng S (2012) Recent advances of FLOWERING LOCUS T gene in higher plants. International Journal of Molecular Sciences 13: 3773-3781.

Yamagishi N, Kishigami R and Yoshikawa N (2014) Reduced generation time of apple seedlings to within a year by means of a plant virus vector: a new plant-breeding technique with transmission of genetic modification to the next generation. Plant biotechnology Journal 12: 60-68.

Yong L, De Chun L, Bo W and Zhong Hai S (2006) Genetic diversity of pummelo (Citrus grandis Osbeck) and its relatives based on simple sequence repeat markers. Chinese Journal of Agricultural Biotechnology 3: 119-126. 